developments in the scientific and technical fields every bit as much as their practising opposite numbers, that is, their potential clionts. Annual weekends could meet this requirement if the necessary backing from authoritativo quartors were forthcoming. The subject-matter for such refresher courses is more or less woll known to ovory tochnical translator: techniques and jargon.

Beginners must naturally koop strictly to the original, but with experience a certain latitude becomes possible and desirable. For example, every language has its typical grammatical constructions. Normally, translating is done word for word with the minimum of roarrangomont to givo adoquato readability. Perhaps more acceptable results could be achieved faster if translators regarded it as part of their task to translato also grammatical construc. tions. 'Ihe substance of the original may come through even more clearly in this way.

Another technique which sounds scarcely relevant, but is extremely important from a practical point of view, is typing. The better a translator can type, the moro time and enorgy he has for tho actual work of translating. A quarter of an hour, or even longer, looking for the right word is most uneconomical working, yot it is so casy for ono translator to phone another who knows the answer and might reciprocate on somo future occasion.

The image of technical translating is small, pettifogging and 'uninteresting'. All this it certainly is on occasion, especially when output alono is important for economic reasons.

In tho wider picture, however, science and technology have many important small links in the chain from the original conception to the final achievoment, whatever it happens to be, and technical translating is one such link in the information and communications field. Perhaps this link is a more vital ono than is genorally appreciatod because, in the past, too many amateurs have had to do it or it would, by and large, not have been done at all.

\section{THE SECOND MASER MILESTONE}

Advances in Quantum Electronics

Edited by Prof. Jay R. Singer. Pp. xvii +641 . (New York and London: Columbia University Press, 1961.) 15 dollars; $120 s$.

THE title of this book rather suggests that it is a comprohonsivo roviow of the present state of quantum electronics, and so it is, for tho expert.

The new field of quantum electronics was firmly established at its first intornational conference, held in Soptembor 1959. Tho socond intornational conference was held in Berkeley, California, in March 1961 , and the present volume is really the conference report. It comprisos tho summaries and parts of tho discussions of about seventy papors prosontod at the meeting. The articles vary in length from a few paragraphs to about ten pages, depending presumably on the whims of the authors, and their contents are usually devoted to aroas of the subject whoro recent advances have been made, with relatively little space devoted to giving the background of the topic. Thus the book must be regarded as primarily for the worker in quantum electronics, and a newcomer will probably wish there wore more review articles. Even so, a casual rcader can scarcely fail to be impressed by the picture which emerges, of a most exciting and rapidly developing field of activity.

It is natural to compare this book with tho report of the first conference, published under the title of Quantum Electronics and edited by Dr. C. H. Townes, to see how the ideas and work there reported have progressed. Two main features emerge. In 1959 it was rather novel to have a microwavo amplifier or oscillator using the maser principle, but now this is so commonplace that relatively little space is dovoted to masers. The big step forward has come with the application of maser prineiples to optical frequencies, and has led to the laser, or the generation of coheront infra-red and visible light. From the high proportion of papers devoted to lasers it is clear that interest has now swung away from microwave masers, for the very good reason that the new field provides all sorts of challenging problems and exciting possibilities. To mention a few : thero is the possibility that modulated visiblo light can be used for communication purposes both terrestrially and in outer space; so intense can be the radiation from a lasor that a wide variety of second ordor effects may be observable, such as the goncration of higher harmonics of optical frequoncies, and the production of far-infra-rod radiation by the mixing of two optical frequencies; alternatively, just the study of the effects produced by subjecting materials to intense radiation fields should in itself be of considerable interest. All thoso possibilities and many others were discussed at the conference, and there aro papers describing the present state of progress. As no developments of this magnitude can take place without accompanying advances in techniques there are papors dealing with all aspects of laser technology: materials, light sources, optical systems and so on. But in nearly overy caso the relevant paper is short, and probably omits as much as it reveals.

One section is entitled, "Some New Ideas and Accomplishments". I would have thought that these sentiments should have applied to tho wholo volume, and its publication will be widely welcomed by the considerable number of physicists and electronic engineers who are at present exploiting the field of quantum electronics. K. W. H. Stevens

\section{ASTRONOMY IN EVOLUTION}

A History of Astronomy

By A. Pannekoek. Pp. $521+24$ plates. (London : (Feorgo Allen and Unwin, Ltd., 1961.) 65s. net.

$T$ IHE main problem facing an author attompting to write about the history of any science is to decide on the amount of detail which should be included; too much detail and the reader loses the main gist of the story, too little and the story tends to become a string of gonoralizations. The result Inust always be a compromiso and especially is this so in a history of astronomy which nust go back before tho beginnings of civilization and the advent of written records. 'The late Prof. Pannekoek, well known as a practising astronomer, has managod to steor a middle courso between too many facts and too much generalization. On this important criterion his book scores a considerable success. 